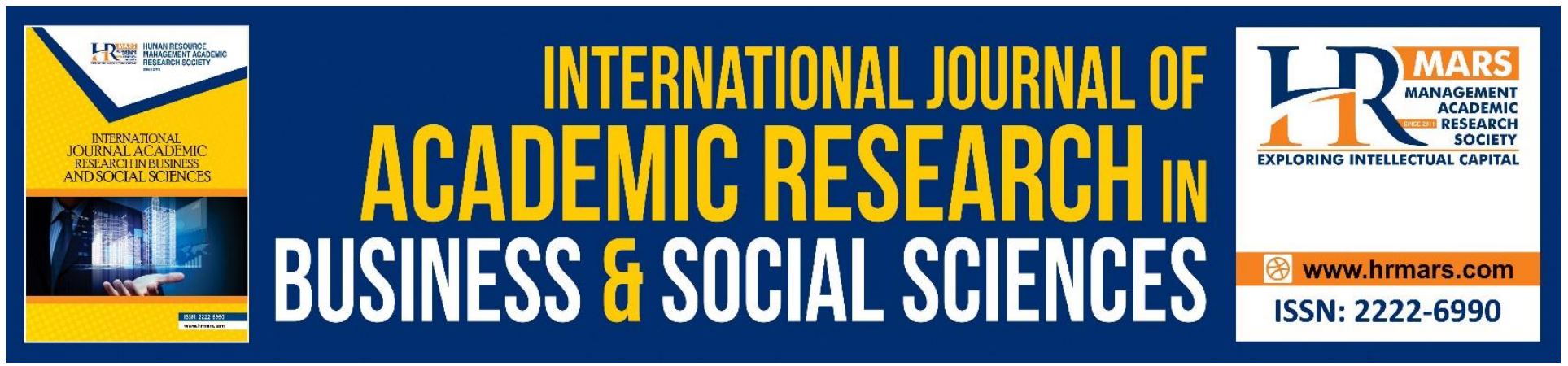

\title{
Entrepreneurial Intentions among Italian Students: The Role of Gender
}

\section{Luana Serino \\ Gaetano Buccino}

To Link this Article: http://dx.doi.org/10.6007/IJARBSS/v9-i3/5801

DOI: $10.6007 /$ IJARBSS/v9-i3/5801

Received: 1 Feb 2019, Revised: 15 Feb 2019, Accepted: 27 Feb 2019

Published Online: 14 March 2019

In-Text Citation: (Serino \& Buccino, 2019)

To Cite this Article: Serino, L., \& Buccino, G. (2019). Entrepreneurial Intentions among Italian Students: The Role of Gender. International Journal of Academic Research Business and Social Sciences, 9(3), 1309-1326.

\section{Copyright: (C) 2019 The Author(s)}

Published by Human Resource Management Academic Research Society (www.hrmars.com)

This article is published under the Creative Commons Attribution (CC BY 4.0) license. Anyone may reproduce, distribute, translate and create derivative works of this article (for both commercial and non-commercial purposes), subject to full attribution to the original publication and authors. The full terms of this license may be seen

at: http://creativecommons.org/licences/by/4.0/legalcode

Vol. 9, No. 3, 2019, Pg. 1337 - 1355

Full Terms \& Conditions of access and use can be found at http://hrmars.com/index.php/pages/detail/publication-ethics 


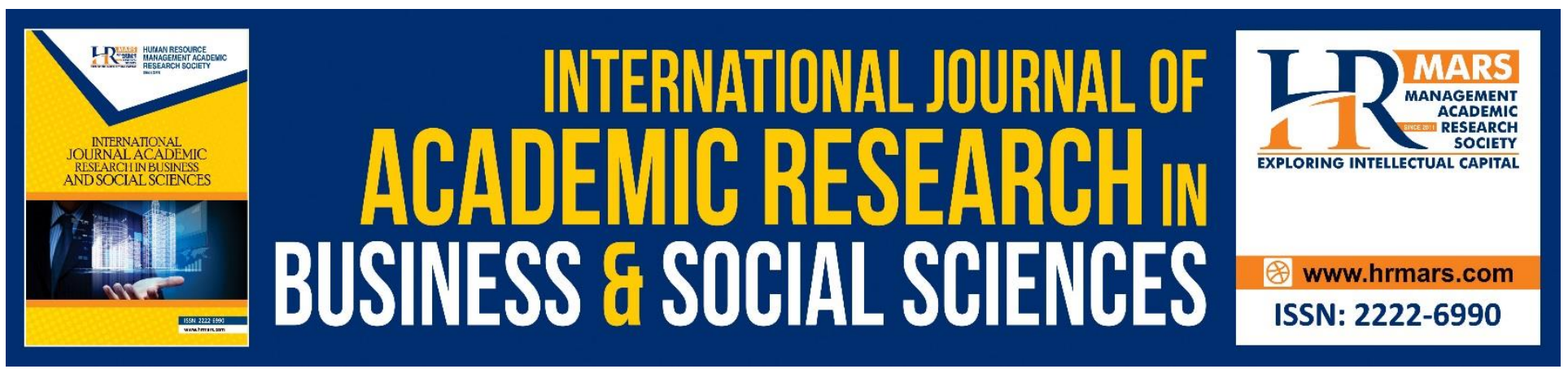

\title{
Entrepreneurial Intentions among Italian Students: The Role of Gender
}

\author{
Luana Serino \\ Department of Economics, University of Campania L. Vanvitelli \\ Corso Gran Priorato di Malta, 81043, capua, Caserta, Italy \\ Email: luana.serino@unicampania.it \\ Gaetano Buccino \\ Department of Economics, University of Campania L. Vanvitelli \\ Corso Gran Priorato di Malta, 81043, Capua, Caserta, Italy \\ Email: gaetano.buccino@unicampania.it
}

\begin{abstract}
There is general agreement that personality factors are determinant elements for university students to decide an entrepreneurial career. This empirical study aims at assessing what behavioral aspects impact on the intentions of students, using a sample of 347 Italian undergraduates and the trait model as theoretical framework. Furthermore, we want to explore personality differences among female and male students, comparing their intentions towards an entrepreneurial career. Thus, we are motivated to explore the relationship between personal traits, gender and entrepreneurial intentions, using a mixed method. This paper provides a new model that helps to understand the students' entrepreneurial intentions by adding the gender role. The findings revealed that some personality traits affect Italian undergraduates in engaging an entrepreneurial activity. Our study concluded that men tend to have higher self-confidence than women and this may affect their entrepreneurial intentions. Hence, our results suggested that more in-depth analysis concerning the female entrepreneurship should be put in place.
\end{abstract}

Keywords: Entrepreneurship, Gender, Trait model, Undergraduates, University Students.

\section{Introduction}

Due to lack of a universally-accepted definition of entrepreneur or entrepreneurship, there is no welldefined population of entrepreneurs. Despite intensive inquiry, relatively little is known about the entrepreneur, the central figure in entrepreneurship. Much of the research in entrepreneurship has been founded upon the premise that entrepreneurs have distinctive individual characteristics which can be identified and used to indicate a potential entrepreneur. In particular, the behavioral aspects 
have been argued as the best method to identify an entrepreneur. In an earlier paper, Olson (1985) linked the strategic planning to entrepreneurial activity, as entrepreneurs plan in more depth than other individual. Entrepreneurship is a risky process and not everyone is able to start a new business (Fatoki, 2010). A long tradition of academic research is devoted to the question of why some people choose to be self- employed, founding their own company (Franke \& Lüthje, 2004). Different conceptual models may explain the various factors that affect this process (Bygrave, 1989; Bygrave \& Minniti, 2000; Moore 1986). The entrepreneurial intentions are influenced by different elements, such as past life experiences (Minniti \& Bygrave, 2003; Politis, 2005), personal formation (Harris \& Gibson, 2008; Hussain, Scott \& Hannon, 2008; Hussain, Scott \& Matlay, 2010) and personal attitudes (Krueger, Reilly \& Carsrud, 2000).

In Italy, the number of "pink" businesses increased in the last years (Cerved Report, 2017). Therefore, Italy is in fourth place-after Norway, France and Sweden-in the world for the number of women on corporate boards (Bianco, Ciavarella \& Signoretti, 2011; Rossi, Capasso \& Galasso, 2017).

However, many empirical studies have found that men have a higher attitude to form a new business than women. This preference is not due to a greater capacity but rather to the behavioral aspects that are typical in women. In particular, these gender differences are caused by changes in selfefficacy. Kolvereid (1996) found that males have a significantly higher preference for selfemployment than females. Furthermore, in according to the literature (Kirkwood, 2009), women tend to be less confident than men and so they are less likely to form an own business. In this sense, the role of gender enhances our understanding of entrepreneurial intention. However, little is known about how self-confidence affects entrepreneurs' decisions and actions in their ongoing business.

We are motivated to further explore the relationship between personal traits, gender and entrepreneurial intentions. Moreover, in academic research, the relevance of the entrepreneurship phenomenon is a growing issue.

This study wants to extend prior research examining the entrepreneurial intention of students in Italy. Indeed, the aim of this paper is to investigate the entrepreneurial intention of Italian business students according to the Traits Model. In particular, our study analyses survey data from a sample of Italian undergraduates concerning their entrepreneurship intentions. The research methodology used was a mixed method approach. In a first qualitative phase, data are collected through selfadministered questionnaires. In a second quantitative phase, a multiple regression analysis was performed to identify the factors affecting the students' intention to become entrepreneurs. In addition, we analyzed the correlation between gender and intention to become entrepreneurs because the female entrepreneurship has an important role in the economic growth for Italy.

More precisely, we submitted a questionnaire and adopted a two-step quantitative approach to test our research hypotheses. The purpose of this study is to analyze a sample of Italian university students and assess differences in entrepreneurial aspirations among female and male students.

In this paper, we try to answer the following questions:

1. Are there any differences between groups female and male students in terms of entrepreneurial intentions?

2. Are behavioral aspects equally important for the entrepreneurial intentions? 
In answer to the first research question, we performed a T-test for equality of means; subsequently, to assess what factors are correlated with the entrepreneurial intentions we adopted an Ordinary Least Squares (OLS) regression model.

In summary, univariate analysis examines differences across male and female students. Multivariate regression analyzes how behavioral factors and gender are correlated with entrepreneurial intentions.

Our empirical study contributes to the extant literature because the studies concerning the relationship between personal traits of individuals and the entrepreneurial tendency are still inconclusive. Furthermore, there is a main motivation for our research. When designing entrepreneurship education programs, it is important to understand behavioral aspects that impact on entrepreneurial projects so as to be able to best cater to students' needs. Intentions and inclinations about entrepreneurship can be learned, measured and improved (Hatten \& Ruhland, 1995). Prior research stated that entrepreneurial skills can be learned (Kuratko, 2005) as is demonstrated by the growing number of entrepreneurship programs at universities (Matlay, 2006). Our empirical study contributes to the limited understanding of how behavioral aspects and gender affects the start-up decision, but more research required. A key outcome of this paper is that it provides directions for further research to more fully understand this phenomenon. Following Zhao, Seibert \& Hills (2005), our study relies on the assumption that entrepreneurial intentions are strongly related to personal traits. While there is a significant stream of the literature that examined the determinants of entrepreneurial intentions (e.g. Zhao \& Seibert, 2006), there is a lack of research focusing on the correlation between gender and entrepreneurial intentions. Moreover, much of the studies that seek to explain entrepreneurial intentions is flawed (Mitchell, Busenitz, Bird, Marie Gaglio, McMullen, Morse \& Smith, 2007). In this study we aim to fill this gap, using a mixed methodological approach aimed to investigate in depth the correlation between behavioral aspects and entrepreneurial intentions. Furthermore, our study contributes on gender research as it is aimed to investigate whether women are less likely to be entrepreneurs.

We hope that our examination of the interactions between individuals' traits, gender and entrepreneurial career intention will contribute meaningfully to the ongoing discussion of the role and effectiveness of entrepreneurship education for students.

The remainder of this essay is structured as follows. After the introduction, the second section presents the related literature and the research hypotheses. In the third section, we define the research methodology, variables and data. Subsequently, we present the main results of the study. Finally, we present the research conclusions of our paper and some theoretical and managerial implications.

\section{Literature Review}

Personal traits and entrepreneurial intentions

Literature about entrepreneurial intention has focused on issues such as social contexts and personality traits to explain the reasoning behind and individual's intention to become an entrepreneur. Thus, literature about entrepreneurial intent has been studied mainly using three models: social factors model, environmental factors model, and trait approach. 
However, the most used approach in researching the characteristics of entrepreneurs has been the use of personality theory emphasizing individual traits. The personality approach to identifying entrepreneurial tendencies consists of the direct measurement of personality traits or motivational tendencies possessed by entrepreneurs. However, just as there are different points of view about the nature of entrepreneurship, and it is difficult to identify the entrepreneur (Chell, Haworth \& Brearley, 1991). Many definitions associate innovative approaches, creativity and the ability to take risks with business activity. These features underlie the motivation for entrepreneurship (Olson, 1985).

The Social Factors Model examines the personal background and family background, stage of career, early life experiences (Robinson, Stimpson, Huefner \& Hunt., 1991; Alstete, 2002; Gibb, 1993; Green, David, Dent \& Tyshkovsky, 1996; Zhao et al.,2005).

The Environmental Factors Model is related to the contextual factors such as value of wealth, tax reduction the impact of market conditions, timing of opportunities in the career process, supportive social and economic culture (Alstete, 2002; Green, David, Dent \& Tyshkovsky, 1996). In accordance with this stream of literature (Pittaway \& Cope, 2007a; Carayannis, Evans \& Hanson, 2003) individuals' entrepreneurial intentions can be shaped by cultural values and the environment in which he or she is located.

Then, the Trait Model (Gozukara \& Colakoglu, 2015) focus on individual factors, personality characteristics of entrepreneurs. In this model, the characteristics of successful and unsuccessful enterprises are investigated (Bygrave \& Hofer, 1992; Chye Koh, 1996; Littunen, 2000). The Trait Model rests on the assumption that entrepreneurs have certain unique characteristics, attitudes and values that distinguish them from others (Thomas \& Mueller, 2000; Koh,1996). According to Trait Approach, entrepreneurs are assumed to have certain personality traits which made them unique. Furthermore, the Trait Model has been a significant element of research on entrepreneurship. Indeed, a large body of the literature have analyzed certain traits of personality as the characteristics of entrepreneurs (Entrialgo, Fernández \& Vázquez, 2000; Stewart, Carland, Carland \& Watson, 1998; Stewart, Carland, Carland, Watson, \& Sweo, 2003). Furthemore, Franke and Lüthje (2004) showed that administrative difficulties, banks' reluctance to finance new business projects, the fear of failure, risk aversion, are also factors that can derail an individual's entrepreneurial tendency (Shinnar, Pruett \& Toney, 2009).

Although not specifically developed for students, the different conceptual model structures developed in the academic research might explain their entrepreneurial inclinations as well as the tendencies of any other population.

In addressing our research questions question, our study is aimed to investigate the personality traits that are significantly correlated with entrepreneurial intentions.

However, there is no agreement on the number of traits specific to the entrepreneur, or their validity (McStay, 2008). For this reason, our research model includes three classic themes in the literature: need for achievement (or achievement motivation), risk-taking propensity, and self-confidence.

A summary of the main empirical evidence concerning the personal characteristics used in our study is presented below.

Need for achievement: The dependability facet of Need for achievement reflects the extent to which one is organized, deliberate, and methodical. The individual characterized by this quality sets targets 
and strive for these targets through their own efforts, demonstrate a higher performance in challenging tasks (Zhao \& Seibert, 2006). The need for achievement theory of McClelland (1961) is one of the most applied theories on entrepreneurship. Indeed, McClelland was the first that posited that a high need for achievement may predispose a person to seek an entrepreneurial position to attain more achievement satisfaction that could be correlated with other jobs (Entrialgo et al., 2000; Stewart et al., 2003). In accordance with the study made by Collins, Hanges \& Locke (2004), achievement motivation is significantly correlated with both choice of an entrepreneurial career and entrepreneurial performance, because the need for achievement is the reason that leads the person to struggle for success (Littunen, 2000; Sagie \& Elizur, 1999).

Hp1. The need for achievement positively impacts on the entrepreneurial intentions of Italian students.

Risk taking propensity: Risk taking propensity refers to the propensity of an individual to exhibit risk avoidance in risky and ambiguous situations. Entrepreneurship is historically associated with risk taking. In one of the earliest examples, Cantillon (1755), stated that the main factor in differentiating entrepreneurs from employed workers was the uncertainty and risk taken by the former (Entrialgo et al., 2000; Thomas \& Mueller, 2000).

Hp2. The risk-taking propensity has a positive effect on the entrepreneurial intention of Italian students

Self-confidence: The self-confidence pertains to one's confidence in her or his skills and ability to successfully undertake career-related activities. Then, prior studies indicated that individuals' confidence plays a key role in determining the level of interest in pursuing an entrepreneurial career (Bandura, 1992). Research in the field of entrepreneurship has highlighted the importance of selfconfidence as a key factor in determining human agency, showing how individuals with higher entrepreneurial self-efficacy have higher entrepreneurial intentions and are more likely to believe they also have an actionable idea (Krueger et al., 2000; Siegel, Wright \& Lockett, 2007; Wang, Wong, \& Lu, 2002). In addition, the lack of confidence may to act as a constraint, affecting individuals' ability to access finance and curtailing their growth aspirations (Kirkwood, 2009).

$H p 3$. The self-confidence has a positive effect on the entrepreneurial intentions of Italian students

In summary, in this study we investigate the personality characteristics are used to define the entrepreneurial profile of students. In particular, we verify which personal data are significant determinants of entrepreneurial tendency of the students. In accordance with prior studies (Gurol \& Atsan, 2006), our research uses the trait model of entrepreneurship and examines traits associated with entrepreneurship, namely need for achievement, risk taking propensity and self-confidence. These characteristics are used as proxies of the entrepreneurial behavior of individuals because they are frequently used in in the entrepreneurship literature.

Gender and Career Self-Efficacy

In addition to personal traits mentioned above, a robust body of literature stated that gendered characterizations may impede the full realization of business potential (Robb \& Watson, 2012). Different research has revealed less interest among girls than among boys in entrepreneurial careers 
(Kourilsky \& Walstad, 1998; Marlino \& Wilson, 2003). The factors contribute to the disparity between men and women in entrepreneurial career interests are related mainly to the behavior and motivations. There is significant evidence to suggest that women are more likely than men to limit their career aspirations because they believe that they lack the necessary capabilities (Kirkwood, 2009). Therefore, a substantial amount of empirical evidence found out that gender is a significant variable in understanding differences in career self-efficacy (Lent \& Hackett, 1987; Nevill \& Schleckler, 1988). Thus, women are likely to have lower expectations than men for success in a wide range of occupations (Bandura, Barbaranelli, Caprara, \& Pastorelli, 2001; Betz \& Hackett, 1981; Scherer, Brodzinski, \& Wiebe, 1990). Because women are more risk averse and less self-confident compared to men, they tend to be less likely to be successful entrepreneur. A large part of the literature says that women encounter obstacles associated with their gender in order to gain the credibility and resources in the business world, not for a lack of abilities of women, but for more complex reasons (Aliyu, Ahmad, \& Nordin, 2019). These reasons are directly connected to the personal and professional life of working women. Indeed, it tend to be characterized by pause period, more or less long, for childbirth and care which compromise career advancement. Thus, women can hardly reach top management positions and to develop adequate savings of resources to invest in their business ventures (Marlow \& Patton, 2005). In this sense, Carter (2000: 174) argues that: "Female business owners use substantially less capital at start-up than do male business owners. In total, men used three times more start-up capital than women, (and this) was related positively and significantly to current value of capital assets, sales turnover, and total number of employees".

Given the important gender differences in self-efficacy in general and entrepreneurial self-efficacy suggested by the literature, we were motivated to test an additional hypothesis:

Hp4. Women are less likely to have entrepreneurial intentions

Then, in order to clarify the research objectives of our paper we provide the following conceptual framework (Figure 1).

Figure 1. Conceptual framework

\begin{tabular}{|c|c|c|c|}
\hline Need for achievement & Entrepreneurial \\
\hline Sisk taking propensity & Intentions \\
\hline
\end{tabular}

\section{Sample and Method}

We collected survey data of a sample of 347 Italian students that is representative only for the population surveyed. We surveyed business students of three Italian universities; so, the participants in this research were students who were enrolled in economics courses. Hence, the findings can only apply business students rather than the general population. However, by focusing solely on business 
undergraduates, the results are more readily compared with previous studies, making the findings more insightful to researchers and practitioners.

Respondents were anonymous to ensure unbiased responses. According to the literature (Harris \& Gibson, 2008), business students because they are more likely to have entrepreneurial inclinations. Moreover, higher levels of education increase the propensity to start a business (Acs, Armington, \& Zhang, 2007; Brockhaus, 1982; Colombo \& Grilli, 2010).

The majority of students who took part in the study were about. 25 years. In accordance with the literature, students plan to start their own business around the age of 25 years old (Staniewski \& Szopiński, 2013). Based on international literature students surveyed belong to Generation $Y$, also known as Millennials (Kumar, 2008; Hobart \& Sendek, 2014). This generation tend to believe in themselves, to feel optimistic about the future and to be ambitious.

In the preliminary stage of the research, the questionnaire was pre-tested on 100 students. The students who participated in the questionnaire' pre-test phase were not included in the final empirical sample.

More specifically, the questionnaire submitted in October 2018 was divided into two parts.

In the first part, following Gürol \& Atsan (2006), questions have been submitted to students in order to quantify own tendency or inclination to start own business after graduation. The second part includes questions related the individual traits of students surveyed. In line with prior studies (Gibb, 2002), we developed a four-point Likert-based questionnaire (ranging from 1, strongly disagree, to 4 , strongly agree). This kind of scale avoids the central tendency bias because it adopts a scale of even numbers (Si \& Cullen, 1998).

The data collected have been input into Stata 15, a statistical software package.

A total of 153 male students and 194 female students were included in our sample. Table 1 revealed that differences in terms of personality exist among Italian undergraduates. So, male students are more likely to assume risk and are more self-confidence compared to female students. Furthermore, male students are more likely to have entrepreneurial aspirations than female students. However, are not significant differences among students in terms of need-achievement.

As in the case of prior research, women in this study are more risk averse and less self-confident compared to men. In addition, women are less likely to have entrepreneurial intentions than men. Instead, there were no significant differences among students in individual's desire for accomplishment, mastering of skills as measured by need-achievement variable. 
INTERNATIONAL JOURNAL OF ACADEMIC RESEARCH IN BUSINESS AND SOCIAL SCIENCES Vol. 9, No. 3, March, 2019, E-ISSN: 222 2-6990 @ 2019 HRMARS

Table 1. Characteristics of Empirical Sample

\begin{tabular}{|l|l|l|l|l|}
\hline & Female students & $\begin{array}{l}\text { Male } \\
\text { students }\end{array}$ & t-statistic & Pr> t statistic \\
\hline Number & 153 & 194 & & \\
\hline $\begin{array}{l}\text { Need for } \\
\text { achievement }\end{array}$ & 3.57 & 3.63 & -0.986 & 0.325 \\
\hline Risk-taking* & 3.57 & 3.67 & -1.874 & 0.062 \\
\hline Self-confidence*** & 3.41 & 3.63 & -3.743 & 0.000 \\
\hline Intention** & 3.29 & 3.39 & -2.198 & 0.029 \\
\hline
\end{tabular}

Subscript $* * *, * *$, and $*$ denotes statistical significance at the $1 \%, 5 \%$, and $10 \%$ levels, respectively.

These results might seem to imply that gender impact on entrepreneurial intentions. The problem with this rather simplistic interpretation is that Table 1 is based on univariate analysis. This type of analysis ignores the possible effects of different variables acting in concert.

So, this shortcoming can be addressed by multivariate analysis.

Therefore, in order to investigate the research hypotheses, the following econometric models have been formalized:

$Y=\alpha+\beta_{1}$ need_achievement $+\beta_{2}$ risk_taking $+\beta_{3}$ confidence $+\beta_{4}$ gender $+\varepsilon$

The dependent variable $Y$, called as Intention, is the mean score of all the answers concerning the inclination to become entrepreneur.

Different studies emphasized the significant importance of intention as an antecedent of planned behavior, such as founding a business and the best predictor of actual behavior (Krueger, Reilly \& Carsrud, 2000). Hence, we took this variable as a dependent measure in order to investigate students' entrepreneurial intentions.

About the independent variable, it is expressive the intentions of student to start new firm.

In particular, they are:

Need for achievement: this variable captures the individual's desire for significant accomplishment, mastering of skills, or high standards. Three items, including "I seek improvements and ways of doing things better", were developed to measure this variable using a four-point Likert format;

Risk-taking: this variable refers to individual's risk propensity. Three items, including "I am likely to invest $50 \%$ of my annual income in a new business project", were developed to measure this variable using a four-point Likert format;

Self-confidence: this variable captures the individual's self-confidence and in his/her skills. Three items, including "I can speak in public without difficulties" were developed to measure this variable using a four-point Likert format;

For each variable employed, the items are summed to arrive at a behavioral score.

Gender: was dummy coded 1 for female subjects and 0 otherwise. We included Gender variable to assess whether gender differences exist in entrepreneurial intentions. 
INTERNATIONAL JOURNAL OF ACADEMIC RESEARCH IN BUSINESS AND SOCIAL SCIENCES

Vol. 9, No. 3, March, 2019, E-ISSN: 222 2-6990 @ 2019 HRMARS

\section{Results}

Before commenting on the panel analysis and answering the hypothesis of research, it is necessary to make some considerations regarding the correlation analysis between the variables distributed normally using the Pearson indices correlation matrix (Table 2). Table 2 shows that many variables are significantly correlated, but often Pearson's indices are low.

Table 2. Pearson correlation matrix

\begin{tabular}{|c|c|c|c|c|}
\hline & $\begin{array}{l}\text { Need for } \\
\text { achievement }\end{array}$ & Risk-taking & Self-confidence & Gender \\
\hline $\begin{array}{l}\text { Need for } \\
\text { achievement }\end{array}$ & 1 & & & \\
\hline Risk-taking & $0,262^{* * *}$ & 1 & & \\
\hline Confidence & 0,040 & $0,235^{* * *}$ & 1 & \\
\hline Gender & 0,053 & 0,099* & $0,194^{* * *}$ & 1 \\
\hline
\end{tabular}

Subscript $* * *, * *$, and $*$ denotes statistical significance at the $1 \%, 5 \%$, and $10 \%$ levels, respectively.

We performed OLS analysis to verify the association between variables. Several important findings emerged. The regression results are presented in the following table (Table 3).

Before implementing the regression model, we tested the assumptions of the model: normality of dependent variable (Shapiro-Wilk test); homoskedasticity (Breusch-Pagan test); and absence of autocorrelation between residuals (Durbin-Watson test). The aforementioned tests (untabulated) are statistically significant thus our empirical data respect the base assumption of OLS regression. 
Table 3. Displays Linear Regression Analysis

\begin{tabular}{ll}
$\mathbf{Y}$ & Intention \\
\hline Constant & $\begin{array}{l}2.173(10.67)^{*} \\
* *\end{array}$ \\
$\boldsymbol{X}_{1}$ & $0.028(0.73)$ \\
$\boldsymbol{X}_{\mathbf{2}}$ & $0.099(2.33)^{* *}$ \\
& $\begin{array}{l}0.196 \\
\boldsymbol{X}_{3}\end{array}$ \\
& $0.042(0.99)^{* * *}$ \\
$\boldsymbol{X}_{4}$ & \\
\hline $\begin{array}{l}\text { Number of } \\
\text { obs. }\end{array}$ & 347 \\
\hline
\end{tabular}

Anova test

$\begin{array}{ll}\text { R-squared } & \text { Adj R-squared } \\ \mathbf{0 . 1 2} & 0.11\end{array}$

F-Test $11.25^{* * *}$

Subscript $* * *, * *$, and $*$ denotes statistical significance at the $1 \%, 5 \%$, and $10 \%$ levels, respectively.

The results obtained from linear regression show that: Need for achievement variable does not significantly impact on the dependent variable; Risk-taking variable positively and significantly impacts on the entrepreneurial intentions at the 0.05 level; while Self-confidence variable positively and significantly impacts on the entrepreneurial intentions at the 0.01 level.

These results mean that the entrepreneurial intentions increase with increased the risk-taking propensity and the individual' self-confidence.

Finally, the gender dummy variable is not statistically correlated with the dependent variable. This result suggests that the students' gender does not impact on entrepreneurial intentions. Although women are less likely to become entrepreneur (as shown in Table 1), after controlling for other factors that are related to personality characteristics, the gender does not statistically and significantly influence the entrepreneurial intentions. This seems to enhance the key role that personality traits of individuals play in influencing the entrepreneurial intentions. 
INTERNATIONAL JOURNAL OF ACADEMIC RESEARCH IN BUSINESS AND SOCIAL SCIENCES Vol. 9, No. 3, March, 2019, E-ISSN: 222 2-6990 @ 2019 HRMARS

The coefficient of multiple determination with a value of 0.11 implies that approximately $11 \%$ of total variation in Intentions is explained by selected variables while the remaining $89 \%$ is accounted for by factors not specified in the model. $\mathrm{F}$ statistics value of 11.25 shows that the model is significant.

Robustness analysis

To increase the robustness of the results, this research implemented two additional tests. It tested for multicollinearity using the variance inflation factor and tolerance.

As you can see, the sample has no problem of multicollinearity; indeed, VIF and Tolerance tests show normal values (Table 4).

Table 4. Vif and Tolerance tests

\begin{tabular}{|l|l|l|}
\hline Variable & Vif & $\mathbf{1}$ Vif \\
\hline Need for achievement & 1.08 & 0.928 \\
\hline Risk Taking & 1.09 & 0.914 \\
\hline Confidence & 1.19 & 0.877 \\
\hline Gender & 1.04 & 0.958 \\
\hline Mean Vif & 1.09 & \\
\hline
\end{tabular}

\section{Discussion and Conclusion}

This paper has investigated the personality traits that affect Italian university students in engaging an entrepreneurial activity. The test performed to verify the research hypotheses produced results demonstrate that some individual characteristics impact on the undergraduates' entrepreneurial intentions. In particular, we showed that Need for achievement variable does not impact on the entrepreneurial intentions ( $\mathrm{Hp} 1$ is not confirmed), while the Risk-taking variable and the confidence significantly and positively impact on the inclination for entrepreneurship ( $\mathrm{Hp} 2$ and $\mathrm{Hp} 3$ are confirmed). These results are also in parallel with the findings of the previous studies on the theory of entrepreneurial traits (e.g. Gürol \& Atsan, 2006). Furthermore, the T-test for equality of means highlighted that women are less likely to have entrepreneurial intentions, but the role of gender is not significantly correlated with the dependent variable in the regression model ( $\mathrm{Hp} 4$ is partially confirmed). On the other hand, our empirical analysis shows that women are more risk averse and less self-confident compared to men. However, after controlling for other factors related to personality traits, the students' gender is not a significant predictor of interest in pursuing an entrepreneurial career. This seems to enhance the key role personality characteristics play in influencing the intentions to become an entrepreneur. Then, these results suggest female entrepreneurship is merits profounder studies in the future. Indeed, a further study with various examination is expected for this intermingled result.

We found out that female students are less likely to start new business. This result may be related to behavioral aspects typical in women. According to the literature (Ferri, Ginesti, Spanò \& Zampella, 
INTERNATIONAL JOURNAL OF ACADEMIC RESEARCH IN BUSINESS AND SOCIAL SCIENCES Vol. 9, No. 3, March, 2019, E-ISSN: 222 2-6990 @ 2019 HRMARS

2018), women are more risk averse and less self-confident. This result is enhanced further by regression analysis that showed that these factors are significant predictors of the entrepreneurial intentions.

Concerning the role of gender, is known that a large part of the literature says that women encounter obstacles to gain the credibility and resources in the business world, due to their personal and professional life (Carter, 2000; Marlow \& Patton, 2005).

Our empirical research contributes to the academic debate about entrepreneurial intentions, offering a comprehensive investigation on the factors that affects Italian university students' intentions to promote an entrepreneurial project. Due to lack of resources, female entrepreneurs can feel the need to turn to the banking system in order to have those resources necessary for their own businesses. This strand of literature finds the presence, in the credit market, of a taste-discrimination or glass ceiling against women (Cavalluzzo \& Wolken, 2005; Calcagnini \& Lenti, 2008; Calcagnini, Giombini \& Lenti, 2012; Campanella \& Serino, 2019a). Thus, female-managed firms are less likely to obtain a bank loan and furthermore, when they succeed in borrowing, they are charged higher interest rates (Arzu \& Mantovani, 2016) or experience a higher level of denial than men (Campanella \& Serino, 2019b). In this regard, the European Commission is working with European countries to and encourage women to start their own companies (Rubio-Bañón \& Esteban-Lloret, 2016).

\section{Main contributions}

This paper contributes to the academic debate about entrepreneurial intentions because it offers a comprehensive investigation on the drivers that affects students' motivations to promote an entrepreneurial activity (Mitra \& Matlay, 2004; Kuratko, 2005; Matlay, 2006). As literature suggests (Ajzen, 1985; 1991), our findings show that behavioral factors are the most important predictors of entrepreneurial intentions.

Also, our research provides an evidence to develop further understanding of the causal relationship between entrepreneurial intentions and personality traits. This study has several implications for regulators (managerial implications) and researchers (theoretical implication).

With reference to the first ones, it appears vital to introduce classes involving entrepreneurship at an early stage, while high schools and universities should provide to students the skills needed to establish and successfully operate a business in the long term (Pittaway \& Cope, 2007b).

Hence, institutions financing and supporting business activity must take further action towards promoting entrepreneurial behavior among young, cooperating with universities that are potential sources of future entrepreneurs. As a tentative conclusion, it is possible to argue that educational programs in universities could focus upon developing in the students the significant above cited individual characteristics, namely risk propensity and self-confidence. In this sense, team work and business games could be tools for developing such aspects.

For researchers, the present study attempts to introduce a new variable in the theoretical framework that studies the correlation between individual traits and entrepreneurial intentions among students, that is the gender (Ferri et al., 2018). Hence, our conceptual model makes an important contribution to the extant literature on students' entrepreneurial intentions by adding the gender as a new variable to the existing framework. In addition, this study provides evidence to develop a deeper understanding of the correlation between personal traits, gender and entrepreneurial intentions. 


\section{Study Limitations and Directions for New Research}

Our study suffers two main limitations. First, we cannot generalize our findings to other countries. Second, the data for this study were collected through a survey instrument. So, all the observed relationships were reported by the same group of respondents. Therefore, any observed relations may be in part a result of common method effect (Fiske, 1982). However, this limitation is consistent with the limitations of prior empirical studies in this area and of most survey research.

Overall, future research could investigate students' entrepreneurial intentions among different European countries to better understand the drivers of entrepreneurial activities. It would be interesting to analyze differences between students from different countries pursuing similar university courses (e.g. business students or non-business students). Unfortunately, our data do not allow such comparisons. Lastly, it is necessary to develop more empirical studies on gender issues to overcome the aforementioned barriers that affect women entrepreneurship, contributing to the economic growth of a country.

A final issue for future research is generational scale. Further research using participants from different generations is needed to determine the impact of the age differences in the individuals' entrepreneurial intentions.

\section{References}

Acs, Z. J., Armington, C., \& Zhang, T. (2007). The determinants of new-firm survival across regional economies: The role of human capital stock and knowledge spillover. Papers in Regional Science, 86(3), 367-391.

Aizen, I. (1985). From intentions to actions: A theory of planned behavior. In J. Kuhl \& J. Beckman (Eds.), Action-Control: From Cognition to Behavior (pp. 11-39). Heidelberg: Springer.

Ajzen, I. (1991). The theory of planned behavior. Organizational Behavior and Human Decision Processing, 50, 179-211.

Aliyu, R. M., Ahmad, T. S. B. T., \& Nordin, N. B. (2019). The Mediating Role of Innovation on Access to Finance and Business Performance of Women Entrepreneurs. International Journal of Academic Research in Business and Social Sciences, 9(3), 147-159. Doi: 10.6007/IJARBSS/v9i3/5644

Alstete, J. W. (2002). On becoming an entrepreneur: an evolving typology. International Journal of Entrepreneurial Behavior \& Research, 8(4), 222-234.

Doi: https://doi.org/10.1108/13552550210436521

Arzu, D., \& Mantovani, G. M. (2016). The Gender Contribution to the Corporate Governance and the Corporate Performance. Retrieved from:

https://papers.ssrn.com/sol3/papers.cfm?abstract_id=2885413

Bandura, A. (1992). Exercise of personal agency through the self-efficacy mechanism. Self-efficacy: Thought control of action, 1, 3-37.

Bandura, A., Barbaranelli, C., Caprara, G. V., \& Pastorelli, C. (2001). Self-efficacy beliefs as shapers of children's aspirations and career trajectories. Child development, 72(1), 187-206.

Betz, N. E., \& Hackett, G. (1981). The relationship of career-related self-efficacy expectations to perceived career options in college women and men. Journal of counseling psychology, 28(5), 399. 
INTERNATIONAL JOURNAL OF ACADEMIC RESEARCH IN BUSINESS AND SOCIAL SCIENCES

Vol. 9, No. 3, March, 2019, E-ISSN: 222 2-6990 @ 2019 HRMARS

Bianco, M., Ciavarella, A., \& Signoretti, R. (2011). Women on boards in Italy.

Brockhaus, R. H. (1982). The psychology of the entrepreneur. Encyclopedia of entrepreneurship, 3957.

Bygrave, W. (1989). The entrepreneurship paradigm (II): Chaos and catastrophes among quantum jumps. Entrepreneurship Theory and Practice, 14(2): 7-30.

Bygrave, W. D., \& Hofer, C. W. (1992). Theorizing about entrepreneurship. Entrepreneurship theory and Practice, 16(2), 13-22.

Bygrave, W., \& Minniti, M. (2000). The social dynamics of entrepreneurship. Entrepreneurship Theory and Practice, 24(3), 25-36.

Calcagnini, G., \& Lenti, E. (2008). Discriminazione nell'accesso al credito per l'imprenditoria femminile. I vincoli finanziari alla crescita delle imprese, a cura di A. Zazzaro, Roma, Carocci Editore, 45-61.

Calcagnini, G., Giombini, G., \& Lenti, E. (2012). Gender differences in bank loan access (No. 1212).

Campanella, F., \& Serino, L. (2019a). Gender and Financial Constraints: An Empirical Investigation in Italy. International Journal of Financial Research, 10(2). Doi:10.5430/ijfr.v10n2p109

Campanella, F., \& Serino, L. (2019b). Do personal characteristics of manager affect Smes' Access to Bank Loan? International Journal of Economics, Business and Finance, 6(2), 1-14. Available at http://ijebf.com

Cantillon, R. (1755). Essay on the nature of general commerce. Henry Higgs, trans. London: Macmllan. Carayannis, E. G., Evans, D., \& Hanson, M. (2003). A cross-cultural learning strategy for entrepreneurship education: outline of key concepts and lessons learned from a comparative study of entrepreneurship students in France and the US. Technovation, 23(9), 757-771.

Carter, S. (2000). Improving the numbers and performance of women-owned businesses: some implications for training and advisory services. Education+ Training, 42(4/5), 326-334.

Cavalluzzo, K., \& Wolken, J. (2005). Small business loan turndowns, personal wealth, and discrimination. The Journal of Business, 78(6), 2153-2178.

Chell, E., Haworth, J.M., \& Brearley, S.A. (1991). The entrepreneurial personality: Concepts, cases and categories. London: Routledge.

Chye Koh, H. (1996). Testing hypotheses of entrepreneurial characteristics: A study of Hong Kong MBA students. Journal of managerial Psychology, 11(3), 12-25.

Collins, C. J., Hanges, P. J., \& Locke, E. E. (2004). The relationship of achievement motivation to entrepreneurial behavior: A meta-analysis. Human Performance, 17(1), 95-117.

Colombo, M. G., \& Grilli, L. (2010). On growth drivers of high-tech start-ups: Exploring the role of founders' human capital and venture capital. Journal of business venturing, 25(6), 610-626. Doi: https://doi.org/10.1016/j.jbusvent.2009.01.005

Entrialgo, M., Fernández, E., \& Vázquez, C. J. (2000). Characteristics of managers as determinants of entrepreneurial orientation: some Spanish evidence. Enterprise and innovation management studies, 1(2), 187-205.

Fatoki, O. O. (2010). Graduate entrepreneurial intention in South Africa: motivations and obstacles. International Journal of Business and Management, 5(9), 87. Retrieved from https://pdfs.semanticscholar.org/9ea5/1930a6409a8935dffed43405d66d19ec6087.pdf 
INTERNATIONAL JOURNAL OF ACADEMIC RESEARCH IN BUSINESS AND SOCIAL SCIENCES

Vol. 9, No. 3, March, 2019, E-ISSN: 222 2-6990 @ 2019 HRMARS

Ferri, L., Ginesti, G., Spanò, R., \& Zampella, A. (2018). Exploring the Entrepreneurial Intention of Female Students in Italy. Journal of Open Innovation: Technology, Market, and Complexity, 4(3), 27. Doi: doi:10.5539/ibr.v10n6p75

Fiske, D. W. (1982). Convergent-discriminant validation in measurements and research strategies. In D. Brinbirg \& L. H. Kidder (Eds.), Forms of validity in research (pp. 77-92). San Francisco: Jossey-Bass.

Franke, N., \& Lüthje, C. (2004). Entrepreneurial intentions of business students-A benchmarking study. International Journal of Innovation and Technology Management, 1(03), 269-288.

Gibb, A. A. (1993). Enterprise culture and education: understanding enterprise education and its links with small business, entrepreneurship and wider educational goals. International small business journal, 11(3), 11-34.

Gibb, A. (2002). In pursuit of a new 'enterprise'and 'entrepreneurship'paradigm for learning: creative destruction, new values, new ways of doing things and new combinations of knowledge. International journal of management reviews, 4(3), 233-269.

Gözükara, İ., \& Çolakoğlu, N. (2015). The impact of manager support and work family conflict on job satisfaction. Business Management Dynamics, 5(6), 13. Available at www.bmdynamics.com

Green, R., David, J., Dent, M. and Tyshkovsky, A. (1996), "The Russian entrepreneur: a study of psychological characteristics", International Journal of Entrepreneurial Behaviour \& Research, Vol. 2 No. 1, pp. 49-58.

Gürol, Y., \& Atsan, N. (2006). Entrepreneurial characteristics amongst university students: Some insights for entrepreneurship education and training in Turkey. Education+ Training, 48(1), 25-38. Doi: DOI 10.1108/00400910610645716

Harris, M. L., \& Gibson, S. G. (2008). Examining the entrepreneurial attitudes of US business students. Education+ Training, 50(7), 568-581. Doi: https://doi.org/10.1108/00400910810909036

Hatten, T. S., \& Ruhland, S. K. (1995). Student attitude toward entrepreneurship as affected by participation in an SBI program. Journal of Education for Business, 70(4), 224-227.

Hussain, J. G., Scott, J. M., \& Hannon, P. D. (2008). The new generation: characteristics and motivations of BME graduate entrepreneurs. Education+ Training, 50(7), 582-596. Doi: https://doi.org/10.1108/00400910810909045

Hussain, J. G., Scott, J. M., \& Matlay, H. (2010). The impact of entrepreneurship education on succession in ethnic minority family firms. Education+ Training, 52(8/9), 643-659. Doi: https://doi.org/10.1108/00400911011088962

Hobart, B., \& Sendek, H. (2014). Gen Y now: Millennials and the evolution of leadership. John Wiley \& Sons.

Kirkwood, J. (2009). Is a lack of self-confidence hindering women entrepreneurs? International Journal of Gender and Entrepreneurship, 1(2), 118-133. Doi:

https://doi.org/10.1108/17566260910969670

Kolvereid, L. (1996), "Prediction of employment status choice intentions", Entrepreneurship Theory and Practice, Vol. 21, pp. 47-57

Kourilsky, M. L., \& Walstad, W. B. (1998). Entrepreneurship and female youth: Knowledge, attitudes, gender differences, and educational practices. Journal of Business venturing, 13(1), 77-88. 
INTERNATIONAL JOURNAL OF ACADEMIC RESEARCH IN BUSINESS AND SOCIAL SCIENCES

Vol. 9, No. 3, March, 2019, E-ISSN: 222 2-6990 @ 2019 HRMARS

Krueger, N. F., Reilly, M. D. and Carsrud, A.L. (2000), “Competing models of entrepreneurial intentions", Journal of Business Venturing, Vol. 15, pp. 411-32.

Kumar (2008): Age differences in mobile service perceptions: Comparison of Generation Y and baby boomers; Journal of Services Marketing.

Kuratko, D. F. (2005). The emergence of entrepreneurship education: Development, trends, and challenges. Entrepreneurship theory and practice, 29(5), 577-597.

Lent, R. W., \& Hackett, G. (1987). Career self-efficacy: Empirical status and future directions. Journal of vocational Behavior, 30(3), 347-382.

Littunen, H. (2000). Entrepreneurship and the characteristics of the entrepreneurial personality. International Journal of Entrepreneurial Behavior \& Research, 6(6), 295-310.

Marlino, D. L., \& Wilson, F. (2003). Teen girls on business: are they being empowered?. Simmons College School of Management.

Marlow, S., \& Patton, D. (2005). All credit to men? Entrepreneurship, finance, and gender. Entrepreneurship theory and practice, 29(6), 717-735.

Matlay, H. (2006). Researching entrepreneurship and education: Part 2: what is entrepreneurship education and does it matter? Education+ Training, 48(8/9), 704-718.

McClelland, D. C. (1961) The achieving society. Princeton, N. J., D. Van Nostrand Co.

McStay, D. (2008). An investigation of undergraduate student self-employment intention and the impact of entrepreneurship education and previous entrepreneurial experience: School Of Business,Bond University,Australia

Mitchell, R. K., Busenitz, L. W., Bird, B., Marie Gaglio, C., McMullen, J. S., Morse, E. A., \& Smith, J. B. (2007). The central question in entrepreneurial cognition research 2007. Entrepreneurship theory and practice, 31(1), 1-27.

Minniti, M., \& Bygrave, W. D. (2003). National Entrepreneurship Assessment United States of America. Executive Report.

Mitra, J., \& Matlay, H. (2004). Entrepreneurial and vocational education and training: lessons from Eastern and Central Europe. Industry and Higher Education, 18(1), 53-61.

Moore, C. F. (1986, August). Understanding Entrepreneurial Behavior: A Definition and Model. In Academy of Management Proceedings (Vol. 1986, No. 1, pp. 66-70). Briarcliff Manor, NY 10510: Academy of Management.

Nevill, D. D., \& Schlecker, D. I. (1988). The relation of self-efficacy and assertiveness to willingness to engage in traditional/nontraditional career activities. Psychology of Women Quarterly, 12(1), 91-98.

Olson, P. D. (1985). Entrepreneurship: Process and abilities. American Journal of Small Business, 10(1), 25-31. Pew Research Center

Pittaway, L., \& Cope, J. (2007a). Entrepreneurship education: a systematic review of the evidence. International small business journal, 25(5), 479-510. Doi: 10.1177/0266242607080656

Pittaway, L., \& Cope, J. (2007b). Simulating entrepreneurial learning: Integrating experiential and collaborative approaches to learning. Management learning, 38(2), 211-233.

Politis, J. D. (2005). Dispersed leadership predictor of the work environment for creativity and productivity. European Journal of Innovation Management, 8(2), 182-204. 
INTERNATIONAL JOURNAL OF ACADEMIC RESEARCH IN BUSINESS AND SOCIAL SCIENCES

Vol. 9, No. 3, March, 2019, E-ISSN: 222 2-6990 @ 2019 HRMARS

Robb, A. M., \& Watson, J. (2012). Gender differences in firm performance: Evidence from new ventures in the United States. Journal of Business Venturing, 27(5), 544-558. Doi: https://doi.org/10.1016/j.jbusvent.2011.10.002

Robinson, P. B., Stimpson, D. V., Huefner, J. C., \& Hunt, H. K. (1991). An attitude approach to the prediction of entrepreneurship. Entrepreneurship theory and practice, 15(4), 13-31.

Rossi, M., Galasso, S., \& Capasso, A. (2017). Women do it Better: An Investigation on the Association between Gender Diversity In Board of Directors and the Financial Performance. International Journal of Economics and Financial Issues, 7(6), 41-50.

Rubio-Banon, A., \& Esteban-Lloret, N. (2016). Cultural factors and gender role in female entrepreneurship. Suma de Negocios, 7(15), 9-17.

Doi: https://doi.org/10.1016/j.sumneg.2015.12.002

Sagie, A., \& Elizur, D. (1999). Achievement motive and entrepreneurial orientation: a structural analysis. Journal of Organizational Behavior: The International Journal of Industrial, Occupational and Organizational Psychology and Behavior, 20(3), 375-387.

Scherer, R. F., Brodzinski, J. D., \& Wiebe, F. A. (1990). Entrepreneur career selection and gender: A socialization approach. Journal of small business management, 28(2), 37.

Shinnar, R., Pruett, M., \& Toney, B. (2009). Entrepreneurship education: Attitudes across campus. Journal of Education for Business, 84(3), 151-159. Doi: https://doi.org/10.3200/JOEB.84.3.151-159

Si, S. X., \& Cullen, J. B. (1998). Response categories and potential cultural bias: Effects of an explicit middle point in cross-cultural surveys. The international journal of organizational analysis, 6(3), 218-230.

Siegel, D. S., Wright, M., \& Lockett, A. (2007). The rise of entrepreneurial activity at universities: organizational and societal implications. Industrial and Corporate Change, 16(4), 489-504. Doi: doi:10.1093/icc/dtm015

Staniewski, M., \& Szopiński, T. (2013). Influence of socioeconomic factors on the entrepreneurship of Polish students. Transformations in Business and Economics, 12, 152-167.

Stewart, W. H., Carland, J.C., Carland, J.W., Watson, W.E. and Sweo, R. (2003), "Entrepreneurial dispositions and goal orientations: a comparative exploration of United States and Russian entrepreneurs", Journal of Small Business Management, Vol. 41 No. 1, pp. 27-46.

Stewart, W. H., Watson, W.E., Carland, J.C. and Carland, J.W. (1998), "A proclivity for entrepreneurship: a comparison of entrepreneurs, small business owners, and corporate managers", Journal of Business Venturing, Vol. 14, pp. 189-214

Thomas, A. S., \& Muller, S. L. (2000). A case for comparative entrepreneurship: Assessing the relevance of culture. Journal of International Business Studies, 31(2), 287-301

Wang, C., Wong, P., \& Lu, Q. (2002). Tertiary education and entrepreneurial intentions. Technological entrepreneurship, 2, 55.

Zhao, H., \& Seibert, S. E. (2006). The big five personality dimensions and entrepreneurial status: A meta-analytical review. Journal of applied psychology, 91(2), 259. Doi: 10.1037/00219010.91.2.259 
INTERNATIONAL JOURNAL OF ACADEMIC RESEARCH IN BUSINESS AND SOCIAL SCIENCES

Vol. 9, No. 3, March, 2019, E-ISSN: 222 2-6990 @ 2019 HRMARS

Zhao, H., Seibert, S. E., \& Hills, G. E. (2005). The mediating role of self-efficacy in the development of entrepreneurial intentions. Journal of applied psychology, 90(6), 1265. Doi: 10.1037/00219010.90.6.1265

Luana Serino (Corresponding author)

Department of Economics, University of Campania L. Vanvitelli

Corso Gran Priorato di Malta, 81043, capua, Caserta, Italy

Email: luana.serino@unicampania.it 